\title{
JUVENILE JUSTICE: KOSOVO CASE
}

\author{
Assist. Prof. Dr. Bashkim Rrahmani, AAB College Prishtina \\ Assist. Prof. Dr.Veton Vula, AAB College Prishtina
}

\begin{abstract}
The paper evaluates policies and practices in juvenile justice from a comparative perspective. It is focused on an analysis of juvenile justice taking into account also work of prosecutors and the judges. In many states of Europe as well as in Kosovo there are developed strategies for reforms of the juvenile justice which have noted qualitative changes and with this, a distinct level of convergence between systems of European states is noted. By using the qualitative methodology and with the use of the method of comparative analysis and method of historical analysis, the authors will be focused on the historical development of the juvenile justice system in Kosovo, under the context of the development of this field in various states of Central and Eastern Europe. The findings and recommendations in this paper could enhance scholarly and institutional tackling of juvenile justice.
\end{abstract}

Keywords: juvenile justice, prosecutor, judge, strategy, reform, institutions. 


\section{Introduction}

Juvenile justice and juvenile offenders are not phenomena of modern times. These phenomena are quite old and these are seen as early as

Laws and legal procedures relating to juvenile offenders have a long history, dating back thousands of years. The Code of Hammurabi some 4,000 years ago (2270 B.C.) included reference to runaways, children who disobeyed their parents, and sons who cursed their fathers. Roman civil law and canon (church) law 2,000 years ago distinguished between juveniles and adults based upon the idea of "age of responsibility." Juvenile justice during the history has changed from a place to the other, from the system to the other, and so on. Thus, in early Jewish law, the Talmud set forth conditions under which immaturity was to be considered in imposing punishment. Moslem law also called for leniency in punishing youthful offenders, and children under the age of 17 were to be exempt from the death penalty (Bernard, 1992). Under fifth-century Roman law, children under the age of 7 were classified as infants and not held criminally responsible. Youth approaching the age of puberty who knew the difference between right and wrong were held accountable. The legal age of puberty (age 14 for boys and 12 for girls) was the age at which youth were assumed to know the difference between right and wrong and were held criminally accountable (History and Development of the Juvenile Court and Justice Process).

The Anglo-Saxon common law that dates back to the $11^{\text {th }}$ and $12^{\text {th }}$ centuries in England was influenced by Roman civil law and canon law. This has particular significance for American juvenile justice because it has its roots in English common law. The Chancery courts in $15^{\text {th }}$ century England were created to tackle petitions of those in need of aid or intervention, generally women and children who were in need of assistance because of abandonment, divorce, or death of a spouse. Through these courts, the king could exercise the right of parenspatriae ("parent of the country"), and the courts acted in loco parentis ("in place of the parents") to provide services in assistance to needy women and children. The principle of parenspatriae later became a basis for the juvenile court in America. The doctrine gives the court authority over juveniles in need of guidance and protection, and the state may then act in loco parentis (in place of the parents) to provide guidance and make decisions concerning the best interests of the child (History and Development of the Juvenile Court and Justice Process). During quite a long period of time, Albanian customary law related to juvenile justice has treated as by not holding responsible children. For their offenses (children) customary law held responsible parents. The delinquency of minors and youth delinquency is a status that is determined by the court based on the national legislation, supported by evidence and the collected data (Newman and Anderson, 1990).

Juvenile justice is a segment of the criminal law of a country, which due to the fact of an abundance of special solutions recently in a number of European states has taken a character of an independent judicial discipline (positive) and also as an academic discipline. Delinquent behavior of minors has two intertwined dimensions: minors as the author of criminal acts and the minors damaged by the criminal acts. In studies conducted on the data about the criminality of minors, it results that in addition to minors as offenders it is a considerable number of minors as victims of crimes committed by their peers (Kriminaliteti $i$ të Miturve në Shqipëri, 2007). Thus we talk about rounded and autonomy entirety of a series of specific solutions compared to adult criminal offenders. This is a collection of legal regulations by which the criminal/criminal status of a minor (as juvenile offenders respectively minors as victims of criminal offenses). This describes a special treatment on juvenile offenses. Thus, this title which often in legal theory is determined as a political-criminal postulate that covers branch with criminal legal rules which are applied against juvenile offenders and which reflect specific characteristics of this branch of justice. This is a justice which is based on the personality of the criminal offender (Taterstrafrecht) and not on the delict (Tatstraftrecht) (Jošević, 2006, pp. 1055-1087).

System of juvenile justice includes: material criminal law -according to legal rules by which the legal criminal status and the position (the rights and duties) of juvenile offenders and the system of penal sanctions against minors (educative measures and jail sentences for minors) as well as alternative educative measures (orders) as means of the diversified model of the juvenile justice; criminal procedure law - the system of rules by which the notion and the competences of juvenile jurisdiction on minors, initiation of criminal procedure, the flow and the steps of procedures in the first instance court according the judicial means for 
juvenile offenders are determined and executive criminal law - the system of legal rules by which competence of state organs and the execution procedure of penal sanctions against minors and other alternative means (educative titles) that are applied against juvenile offenders, are determined. In the criminological aspect when it is talked about juvenile justice that means anti-social behavior anti legal behavior of minors. According to this notion criminality of minors is used to emphasize the criminal activity of all youth without taking into consideration the age (Ragip, 2000 , p. 204). But however, about the age in theory and practice, there are determined limits which indeed do not differ from a country to the other, from a state to the other as we will see further in the paper. As it belongs to the phenomenology of the behavior of minor, it is noted that it consists of the undertaking various acts and activities which more or less are similar to criminal activities of adults, but it is understandable that in concrete cases criminality has also determined features. Thus, the data from criminological research and from the judicial practice have indicated that minor delinquents significantly take part in the criminality against property, in the criminality against security in traffic, in conducting crimes in groups and associations of organized crime, in the activities of distribution and rug consumption, in other activities of violence and especially in the activities against the life and body as well as in sexual delinquents (Ragip, 2000, p. 207).

Reasons for minor delinquency are similar to those of adults, however, in literature are emphasized some factors which to some extent are typical for this age of delinquents. Thus made as factors are mentioned: family environment, family education, the process of education, the impact of means of massive communication especially print, television, film, literature, family, urbanism, migration (Ragip, 2003, p. 193-196).

\section{Modern trends of policies of juvenile justice}

During the last two-three decades, the juvenile justice in Europe has passed through considerable changes and this especially in the states of central and Eastern Europe. In this context, an expansion of diversity measures is noted whereas deprivation of freedom is considered as the "last solution". Regarding the imprisonment sentence for juveniles, in many states, this sentence is executed in specific institutions and for its execution, there are applied some rules and principles which in accordance with the need for treatment and the punitive therapy which response to these youth persons. Thus there exists a general conviction that treatment of persons sentenced to jail for minor should be less loaded with repressive and restrictive measures and more with measures of improvement, re-education, engagement in education, work and cultural activities-entertainment and sports Ragip, 2000, p. 197).

With the exception of some serious crimes most of the juvenile offenders in Europe are treated outside of courts by the informal measures of diversity: for example in Belgium 80\%, Germany around $70 \%$ (Comparative Report Alternative to Custody for Young Offenders). In some cases like Croatia, France, Holland, Serbia, and Slovenia this is a direct consequence of the long-time known principle of giving prosecutors and even police a level of discretion---so-called principle of usefulness. Exceptions, where discretion is not allowed, could be seen in some countries of Eastern and Central Europe but in these cases we should note that crimes against property which cause small damages are not always treated as statutory criminal acts. Italy as the other example gives a judicial pardon that is similar to the diverse exemptions from sentences, but which is given by the judge from the juvenile court. Thus, there exists e broad form of nonintervention or imposing sanctions against minors (formal or non-formal) (Dunkel, 2014). And juvenile courts are significant developments of the 21st century. During the 19th century, accused children for crimes were prosecutedjudged in the courts for adults and they were sentenced with imprisonment together with adults. Big economic changes and social changes with the industrial revolution encouraged, however, new thinking on the place of youth in society. The result was the creation of specialized courts that would deal with minors. The historic mandate of juvenile courts was to save children from criminal life by giving protection care which was given before by natural parents (Neubauer, 2001, p. 176).

Serbian law on juvenile offenders and for their legalcriminal protection distinguishes two groups of juvenile offenders and various sentences depending on age and the weight of the criminal act (Gazeta Zyrtare, 2005). First, children up to 14 years are no penalty responsible no matter the crime committed. Some time ago a boy S. J. (12 years old) in Novi Sad burned out a homeless who 
died from burns and his mother was held responsible for this murder because of negligence of her child (Dnevne vesti, 2017). Good European practices in the field of juvenile justice belong to three main fields: prevention, educative treatment in local communities or centers and socio-professional integration.

On further development of juvenile justice the Resolution XVII of the Congress of the International Association of Criminal Law held in Beijing in 2004, where among the others there were adopted the following suggestions: 1.juvenile offenders are subject to law with all specific characteristics. Based on these reasons the justice systems shall review minor responsibility as a specific question within the elements of criminal act, 2.the age of criminal responsibility shall be 18 (years) whereas the minimum age shall not be lower than 14 in the time of conducting the criminal act, 3.juvenile offenders shall be subject to educative measures or other alternative sentences which are concentrated in the rehabilitation of an individual or if the situation requires, in extraordinary circumstances in the measures of sentence in the traditional meaning, 4.against minors under 14 years old only educative measures shall be applied, 5 . Application of educative measures or alternative sentences which are oriented towards rehabilitation can be broadened according to the requests of interested parties up to 25 years old person, 6. By taking into account criminal acts committed by persons older than 18 years old which to do with minors may be broadened up to 25 years old, 7. Regarding the responsibility of minors the special court organs that have special competences should decide in contrast of those that deal with adults, 8. Decisions of such a court shall be based in the precursory court multidisciplinary surveys open for both parties, and 9.a specific attentions should be paid to the interest of the victim and the human report against them (XVIIth International Congress of Penal Law).

\section{Reforms}

Since the 1990s official registration of crimes committed by minors in Central and Eastern Europe have increased. The need for the reform of juvenile justice has derived from the need of replacing old laws (influenced be USSR) with the European standards (Western) as those found in the principles of the Council of Europe and the UN. The process, however, has produced a little bit more different trends in the criminal policies. As early as in the 1990s we had a dynamic movement for reform of legislation and practice. This is simplified not only with the numerous projects but also in establishing commissions of reform of legislation and in many cases already adoption of laws as in Estonia, Lithuania, Serbia, Slovenia, and the Czech Republic. In a way, the development of an independent juvenile system is the permanent specific of these reforms, as seen, for example, developments in the Baltic States, in Croatia, Czech Republic, Romania, Serbia, Slovakia as well as Turkey. In this line, the importance of the protection measures is considered where also special educative needs for minors get an important place. However, in the Baltic States, there still are not juvenile courts in place.

In order to rein recidivists and especially juvenile offenders, some of these new laws not only involve new community sanctions and possibilities for diversification but also they keep harsh sentences. The lack of adequate infrastructure and extensive acceptance of community sanctions still results in frequent imprisonment sentences. However, developments in Russia, for example, indicate, that return to the model of past sanctions where nearly $50 \%$ of all offenders were sentenced with imprisonment is not presented. Instead of that the forms of probation now are more usual and more used rather than imprisonment sentences (Dunkel, 2014).

What is becoming clear in countries of Central and Eastern Europe is that the principle of the sentence as the last solution is being seriously taken into consideration and the number of tutorial sanctions is reduced. However, it should be noted that the imprisonment of young people and the similar sanctions in the states created in the territories of former Yugoslavia and to some lower extent in Hungary and Poland are almost exceptions in the period before the start of political changes in the early 1990s.

Regarding community sanctions difficulties of building the necessary infrastructure are clear. Initially, a bigger problem with this was the lack of qualified social workers and teachers. This remained a problem since proper training did not appear and did not develop. (Dünkel, Pruin, and Grzywa, 2011). In this regard, Poland has a long tradition on social work. Also, in former Yugoslavia, social workers have been trained following strict supervision as a special sanction in 1960. Concept of "conditioned" responsibility (related to the ability to 
differ) as expressed in the German and Italian justice lately has been approved in Estonia (2002), in Czech Republic (2003) or in Slovakia (for age 14, see Pruin 2011: 1566). This is an important development and for this, it reflects a tendency for reform in the countries of
Central and Eastern Europe influenced by German and Austrian juvenile justice as well as by the international standards. Despite visible and undeniable features, there is an accepted degree of convergence between Western, Central and Eastern Europe.

Table 1: Comparison of the age of criminal responsibility and age ranges for youth imprisonment

\begin{tabular}{|c|c|c|c|c|}
\hline Country & $\begin{array}{l}\text { Minimum age for } \\
\text { educational } \\
\text { measures of the } \\
\text { family/ youth court } \\
\text { (juvenile welfare } \\
\text { law) }\end{array}$ & $\begin{array}{l}\text { Age of criminal } \\
\text { responsibility } \\
\text { (juvenile criminal } \\
\text { law) }\end{array}$ & $\begin{array}{l}\text { Full criminal } \\
\text { responsibility (adult } \\
\text { criminal law } \\
\text { can/must be applied; } \\
\text { juvenile law or } \\
\text { sanctions of the } \\
\text { juvenile law can be } \\
\text { applied) }\end{array}$ & $\begin{array}{l}\text { Age range for youth } \\
\text { imprisonment/ } \\
\text { custody or similar } \\
\text { forms of deprivation } \\
\text { of liberty }\end{array}$ \\
\hline 1 & 2 & 3 & 4 & 5 \\
\hline Austria & & 14 & $18 / 21$ & $14 / 27$ \\
\hline Belgium & & 18 & $16 b / 18$ & $\begin{array}{ll}\text { Only } & \text { welfare } \\
\text { institutions } & \end{array}$ \\
\hline Belarus & & $14 c / 16$ & $14 / 16$ & $14 / 21$ \\
\hline Bulgaria & & 14 & 18 & $14-21$ \\
\hline Croatia & & $14 / 16 b$ & $18 / 21$ & $14 / 21$ \\
\hline Cyprus & & 14 & $16 / 18 / 21$ & $14 / 21$ \\
\hline Czech Republic & & 15 & $\begin{array}{l}\text { 18/18+(mitigated } \\
\text { sentences) }\end{array}$ & $15 / 19$ \\
\hline Denmark & $\mathrm{d} 10$ & 15 & $15 / 18 / 21$ & $15 / 23$ \\
\hline England/Wales & & $10 / 12 / 15 a$ & 18 & $10 / 15-21$ \\
\hline Estonia & & 14 & 18 & $14-21$ \\
\hline Finland d & & 15 & $15 / 18$ & $15-21$ \\
\hline France & 10 & 13 & 18 & $13-18+6 m / 23$ \\
\hline Germany & & 14 & $18 / 21$ & $14-24$ \\
\hline Greece & 8 & 15 & $18 / 21$ & $15-21 / 25$ \\
\hline Hungary & & 14 & 18 & $14-24$ \\
\hline Ireland & & $10 / 12 / 16 a$ & 18 & $10 / 12 / 16$ 18-21 \\
\hline Italy & & 14 & $18 / 21$ & $14-21$ \\
\hline Kosovo & & 14 & $18 / 21$ & $16-23$ \\
\hline Latvia & & 14 & 18 & $14-21$ \\
\hline Lithuania & & $14 c / 16$ & $18 / 21$ & $14-21$ \\
\hline Macedonia & & $14 c / 16$ & $14 / 16$ & $14-21$ \\
\hline Moldova & & $14 c / 16$ & $14 / 16$ & $14-21$ \\
\hline Monte Negro & & $14 / 16 a$ & $18 / 21$ & $16-23$ \\
\hline Holland & & 12 & $16 / 18 / 21$ & $12-21$ \\
\hline Northern Ireland & & 10 & $17 / 18 / 21$ & $10-16 / 17-21$ \\
\hline Norway & & 15 & 18 & $15-21$ \\
\hline Poland & 13 & & $15 / 17 / 18$ & $13-18 / 15-21$ \\
\hline Portugal & 12 & & $15 / 21$ & $12 / 16-21$ \\
\hline Romania & & $14 / 16$ & $18 /(20)$ & $14-21$ \\
\hline Russia & & $14 c / 16$ & $18 / 21$ & $14-21$ \\
\hline
\end{tabular}




\begin{tabular}{|l|l|l|l|l|}
\hline Scotland & $8 \mathrm{e}$ & $12 \mathrm{e} / 16$ & $18 / 21$ & $16-21$ \\
\hline Serbia & & $14 / 16 \mathrm{a}$ & $18 / 21$ & $14-23$ \\
\hline Slovakia & & $14 / 15$ & $18 / 21$ & $14-18$ \\
\hline Slovenia & & $14 / 16 \mathrm{a}$ & $18 / 21$ & $14-23$ \\
\hline Spain & 14 & 18 & $14-21$ \\
\hline Sweden & & 15 & $15 / 18 / 21$ & $15-21 \mathrm{~g}$ \\
\hline Switzerland & $10 / 15 \mathrm{a}$ & $18 \mathrm{f}$ & $10 / 15-22$ \\
\hline Turkey & 12 & $15 / 18$ & $12-18 / 21$ \\
\hline Ukraine & & $14 \mathrm{c} / 16$ & 18 & $14-22$ \\
\hline
\end{tabular}

The age was lowered to 14 in Denmark in January 2010. Subsequently, however, a new government has been elected and Denmark has reverted to the Scandinavian consensus and raised the age of criminal responsibility to 15 again.

a) Criminal responsibility resulting in juvenile detention (youth imprisonment or similar custodial sanctions under the regime of the Ministry of Justice).

b) Only for traffic offences and exceptionally for very serious offences.

c) Only for serious offences.

d) Only mitigation of sentencing without separate youth justice legislation.

e) The age of criminal prosecution is 12 , but for children from 8 up to the age of 16 , the children's hearings system applies, thus preventing more formal criminal procedures.

f) Article 61 of the Swiss Criminal Code for adults provides for a special form of detention, a prison sentence for 18-25 years old young adult offenders who are placed in separate institutions for young adults, where they can stay there until they reach the age of 30 .

g) Youth custody. There are also special departments for young offenders in the general prison system (for young adults until about 25 years of age) (Dunkel, 2014).

\section{Juvenile justice in Kosovo}

Kosovo Parliament in 2010 based on the Kosovo Constitution has adopted the Juvenile Justice Code. This code regulates the procedure of pronouncing sentences and measures against the minors, judicial procedure as well as the procedure of mediation on minors (Article 1, Kosovo Juvenile Code, Nr. 03/L-193). This formulation of the goal of the code is entirely similar with the codes of other countries from Central and Eastern Europe. This means that the Juvenile Justice Code is totally in accordance with the modern trends of justice for minors. The goal of Juvenile justice is defined in that way in order to ensure the wellbeing of minors and that pronounced measure and sentences against minors to be in proportion with the needs for removing them from the path of criminality and their education (Doracak për përgatitje e provimit të jurisprudencës, 2009, p. 157).

The bellow definitions give enough orientations for analysis about what indeed regulate the Juvenile Justice Code. These are:

Child - a person who is under the age of eighteen (18) years.

Minor - a person who is between the ages of fourteen (14) and eighteen (18) years

Young juvenile - a person who is between the ages of fourteen (14) years and sixteen (16) years.

Adult juvenile - a person who is between the ages of sixteen (16) years and eighteen (18)

Young adult - a person who is between the ages of eighteen (18) years and twenty-one (21) years.

Juvenile - a child or a young adult.

Adult - a person who has reached the age of eighteen (18) years.

Specialized education - an educational program tailored to the special needs of the offender to promote his or her overall proper development and reduce the chance of recidivism.

Juvenile imprisonment - a punishment of imprisonment imposed on a minor offender or, in accordance with Chapter IV of the present Code, on an adult. 
Special care facility - an institution that provides treatment for a mental, psychological, social or physical disability.

Guardianship Authority - the department operating within the Centre for Social Work that is responsible for the protection of children.

Juvenile judge - a professional judge who has expertise in criminal matters involving children and young adults and who is competent to exercise the responsibilities set forth in the present Code.

Prosecutor for juveniles - a professional Prosecutor who has expertise in criminal matters involving children and young adults and who is competent to exercise the responsibilities set forth in the present Code.

Juvenile panel - a panel which is constituted in accordance with Chapter $\mathrm{X}$ of the present Code to include at least one (1) juvenile judge and which is competent to exercise the responsibilities set forth in the present Code.

Probation service - the institution which does the execution of measures and alternative penalties (Article 2, Kosovo Juvenile Justice Code, Nr.03/L-193).

From these legal definitions we could draw main characteristics or the justice content for minors and thus the justice system for minors "aims wellbeing of minors and it ensures that every reaction against juvenile offenders has to be in proportion with the circumstances of offender and the criminal act" (Article 3, par. 1, Kosovo Juvenile Justice Code, iKodit, Nr. 03/L193).

And from here, from these definitions we can clearly repeat that juvenile justice is composed of material la, procedural law and the law on execution of sanctions and measures. Kosovo Juvenile justice code, in guiding principles shows that importance and priority is given to educative measures, according to the needs, whereas deprivation of freedoms is pronounced as the last means and it will be limited timely limited as much as possible. During the time when deprivation of freedom is pronounced as the sentence, the minor is offered education, psychological help and medical help accordingly in order to make the rehabilitation easier (Ibid., par.3). Further, code specifies measures and applicable sentences against minors. These are as follows:

1 The measures that may be imposed on minors are diversity measures and educational measures.

2 The punishments that may be imposed on minors are fines, orders for community service work and juvenile imprisonment.

3 Only measures may be imposed on minors who have not reached the age of sixteen (16) years at the time of the commission of a criminal offence.

The duration of any imposed measure or punishment must be established in the decision of the court in accordance with the present Code (Article 7, Kosovo Juvenile Justice Code, Nr. 03/L-193).

Diversity measure aims to eliminate the possibility of repeated crime again by a minor, by using rehabilitation and reintegration approaches (Komentar për ligjin penal për të mitur, juristi.info, fq. 2). When court takes or pronounces measures or sentences it always takes into the account the interest of the minor. Thus, court takes into the account also circumstances, type of criminal offense, age of the minor, level of his psychological development, character and leaning of minors, motives that influenced minor to commit a crime, minor education at the phase, environment and living circumstances and then also it takes into the account if a measure or a sentence was pronounced before as well as the circumstances which could influence the pronunciation of the measure or sentence (Article 8, Kosovo Juvenile Justice Code, Nr. 03/L-193).

From Article 8 to Article 13, Code has regulated the following issues: selection of the applicable measures and sentences, pronunciation of measures against young adult for the offense committed when he was on the age of 16 , pronunciation of measures and sentences against adult for the offenses committed when he was in the age of 16, pronunciation of measures and sentences against young adult for offenses committed while he was young adult, the effects of measures and sentences and evidence of measures and sentences.

Juvenile justice code pays special attention to a specific mechanism which is known as an alternative solution of disputes - the practice of mediation. In such cases 
Prosecutor, judge for minors or the panel for minors can propose a mediation if estimating that it is more appropriate taking into consideration the nature of the criminal act, the circumstances under which the criminal act was committed, the minor's background, the possibility of the reconciliation between the minor and the damaged party, the possibility of deducting damage of the damaged party, the possibility of his rehabilitation and reintegration in the society (Article 14, Kosovo Juvenile Justice Code, and the Law on Mediation Nr. 03/L-057). Kosovo Parliament has adopted the Law on Mediation, whereas based on the needs for mediation and based on the existing legislation the Ministry of Justice together with the Commission on Mediation and with the engagement of some organizations have trained and certified a determined number of mediators that are working in various fields in several centers of Kosovo.

\section{Conclusion}

The juvenile justice systems in Europe and in Kosovo aim towards the protection of children and minors. Approximately solutions for all elements of juvenile justice are similar, as well as definitions regarding what a child, a minor, a young adult, etc., are considered. Basically, more attention is paid to the diverse measures compared to sentences especially compared to the imprisonment sentenced. In some countries, there was a tradition in community organizing and in these countries, social workers dealt with the issues of juvenile justice, like in former socialist countries. Categorization according to the age regarding the responsibility of minors and young adults differs from a country to the other. Differences are noted more in the aspect of institutions which deal with the law on criminal procedure.

Kosovo legislation last year has rounded up an important job by covering with the laws all that belong to juvenile justice in the procedural and material aspects. Measures and sentences are a modern spirit of stressing out the interest of children.

Even though the legislation is completed, even though institutions (not only courts) act in the field of juvenile justice, however, it is a bit early to draw conclusions regarding the prevention affectivity or the affectivity of measures and/or pronounced sentences. Yet, it is the time for an analysis of effects of the legal infrastructure of this field and this analysis should be done by both: academicians and those directly and practically involved in the field of juvenile justice. Only after such an analysis, the affectivity of the entire infrastructure could be measured and the recommendations could be drawn regarding the needs and the sizes for changes in the existing system. 


\section{References}

Andrea Păroşanu, Ineke Pruin, Joanna Grzywa-Holten, Philip Horsfield (Eds.). (2011). Alternatives to Custody for Young Offenders and the Influence of Foster Care in European Juvenile Justice. (http://www.oijj.org/sites/default/files/comparative report alternatives to custody for young offenders.pdf)

Doracak për përgatitjen e provimit të jurisprudencës. (2009). Ministria e Drejtësisë Kosovë/UNDP Kosovë, botimi i tretë,

Frieder Dunkel, (2014). Juvenile Justice Systems in Europe - Reform developments between justice, welfare and 'new punitiveness' Kriminologijos Studijos, 1(31-76). Available at http://eigep.eu/wp-content/uploads/2018/01/Dunkel2014 juvenile justice_Europe.pdf

Halili Ragip (2000). Kriminologjia, Universiteti i Prishtinës Fakulteti Juridik, Prishtinë.

Halili Ragip. (2000). Penologjia, Universiteti i Prishtinës Fakulteti Juridik, Prishtinë.

History and Development of the Juvenile Court and Justice Process, https://uk.sagepub.com/sites/default/files/upm-binaries/19434 Section I.pdf

Comparative Report Alternatives to Custody for Young Offenders, http://www.oijj.org/sites/default/files/comparative report alternatives to custody for you ng offenders.pdf

Juvenile Delinquency, Youth Report (2003) http://www.un.org/esa/socdev/unyin/documents/ch07.pdf Kodi i Drejtësisë për të Mitur, Nr.03/L-193

Kodi Penal i Republikës së Kosovës, KODI NR. 04/L-082

Komentar për ligjin penal për të mitur, Juristi.info

Kriminaliteti i të Miturve në Shqipëri, përgatitur nga Qendra për mbrojtjen e të Drejtave të Fëmijëve në Shqipëri (CRCA) (2007). Tiranë

Ligji Nr.03/L-057 për Ndërmjetësim i Republikës së Kosovës

Neubauer W. David (2001). Debating Crime Rhetoric and Reality, New Orleans: Wadsworth Thomson Learning

Newman, D. J., and Anderson P. R., (1990). Introduction to Criminal Justice. New York: McGraw Hill.

XVIIth International Congress of Penal Law (Beijing, $12-19$ SEPTEMBER 2004 http://www.penal.org/sites/default/files/files/RICPL.pdf

Zakon o maloletni mučiniocima krivičnih dela i krivičnopravnoj zaštiti maloletnih lica ("Sl. glasnik RS", br. $\underline{85 / 2005)}$ 
